\title{
Zinc Diffusion and Availability Affected by Different Sources in Soils of Contrasting Textures
}

\author{
Wedisson Oliveira Santos ${ }^{1}$, Priscila Maria de Aquino ${ }^{2}$, Rafael Lucas Coca Cuesta ${ }^{2}$, \\ Isabela Maísa Honorato Saldanha ${ }^{2}$, Edson Marcio Mattiello ${ }^{2} \&$ Leonardus Vergütz ${ }^{2}$ \\ ${ }^{1}$ Institute of Agrarian Science, Universidade Federal de Uberlândia, Uberlândia, Brazil \\ ${ }^{2}$ Department of Soil Science, Universidade Federal de Viçosa, Viçosa, Brazil \\ Correspondence: Wedisson Oliveira Santos, Institute of Agrarian Science, Universidade Federal de Uberlândia, \\ Rodovia BR 050 km 78, Uberlândia, Minas Gerais 38410-337, Brazil. Tel: 5-319-9991-3146. E-mail: \\ wedosantos@gmail.com
}

Received: October 25, 2018

Accepted: February 24, $2019 \quad$ Online Published: April 15, 2019

doi:10.5539/jas.v11n5p259

URL: https://doi.org/10.5539/jas.v11n5p259

The study was financed in part by the Conselho Nacional de Desenvolvimento Cientifico e Tecnológico (CNPq) and Coordenação de Aperfeiçoamento de Pessoal de Nivel Superior-Brasil (CAPES-Finance Code 001).

\begin{abstract}
Trends in new fertilizer technologies should balance the nutrient release rate from fertilizers with plant demands over time, while developing suitable physical characteristics of the fertilizer's particles. The objective of this study was to evaluate the performance of three zinc fertilizers $\left[\mathrm{ZnO}, \mathrm{ZnSO}_{4}\right.$, and a commercial co-granulated $\mathrm{ZnO}+\mathrm{S}^{0}$ fertilizer (ES_Zn)] on Zn diffusion in soil and their agronomic performances. A Petri dish trial was carried out in order to evaluate the diffusion of $\mathrm{Zn}$ in the soil. The experiment was designed as a factorial scheme $(3+1) \times 2 \times$ 3 , with three $\mathrm{Zn}$ sources, one control treatment (without $\mathrm{Zn}$ application), two soils of contrasting textures (sandy and clay), and three incubation times (1,30 and $60 \mathrm{~d}$ ). The experiment was carried out under a completely randomized design with four replications. Zinc diffusion was assessed according to the method proposed by Degryse et al. (2015) along of incubation times. For that, a $\mathrm{ZnSO}_{4}$ solution or $\mathrm{ZnO}$ suspension was applied by pipetting $15 \mu \mathrm{L}$ of solution or suspension into a small hole $(\sim 0.5-\mathrm{cm}$ deep $)$ in the center of the Petri dish. A single pastille of ES_Zn fertilizer $(30 \pm 0.5 \mathrm{mg})$ was placed in the center of the Petri dish, at the same depth. Soil was watered to $80 \%$ of field capacity. Filter papers (Whatman) were impregnated with $\mathrm{CaCO}_{3}$ and placed on the soil surface. After $2 \mathrm{~h}$ of reaction, the $\mathrm{CaCO}_{3}$-impregnated filter papers were collected, and the precipitated $\mathrm{Zn}$ in the papers was colored with dithizone, giving a pink color. The performance of $\mathrm{Zn}$ sources was evaluated in a greenhouse through a successive maize-soybean-millet crop. The trial was designed as a $2 \times(3 \times 3+1)$ factorial scheme, being two soils (sandy and clay), three $\mathrm{Zn}$ sources $\left(\mathrm{ZnSO}_{4}, \mathrm{ZnO}\right.$, and $\left.\mathrm{ES} Z \mathrm{Zn}\right)$, three $\mathrm{Zn}$ doses $(1.5,3.0$, and $6.0 \mathrm{mg} \mathrm{dm}{ }^{-3} \mathrm{Zn}$ ), and a control treatment. The experiment was a randomized block design with four replications, being the experimental unit composed of a pot with $4 \mathrm{dm}^{3}$ of soil. Pastille ES_Zn, ZnO (as suspension), and $\mathrm{ZnSO}_{4}$ (as solution) were applied at five equidistant points, at $5 \mathrm{~cm}$ below the soil surface. After 30,60 and 60 days of planting, shoot of maize soybean and millet were harvest, oven-dried at $70{ }^{\circ} \mathrm{C}$ for $72 \mathrm{~h}$ (until constant weight), weighed and milled for chemical analysis. ES_Zn fertilizer promoted a delay Zn release in the soil, being effective as a fertilizer only in the last crop (millet), as well as $\mathrm{ZnO}$. Zinc oxide and $\mathrm{ZnSO}_{4}$ had similar performances for increasing $\mathrm{Zn}$ availability in the inner soil portion, but its diffusion in soil was superior when the source was sulfate. The highly soluble $\mathrm{ZnSO}_{4}$ was more effective than $\mathrm{ZnO}$-based fertilizers in terms of plant nutrition, especially for the two first crops. Our results also suggest that $\mathrm{ZnO}$ is solubilized in soil at high $\mathrm{pH}$ (6.6), its dispersion in soil being a key factor for the dissolution rate.
\end{abstract}

Keywords: agronomic efficiency, elemental sulfur, zinc oxide, zinc sulfate

\section{Introduction}

Zinc is an essential element for plant nutrition, and its deficiency appears to be the most widespread and frequent micronutrient deficiency worldwide, causing a decrease in crop yields and nutritional quality (Alloway, 2004; Cakmak, 2008). Zinc deficiency problems are reported in many regions around the world, such as Asia, Central 
America, Africa, and South America, mostly in soils formed on limestone and sandstone (Alloway, 2004). However, for highly weathered soils, including clayey soils such as those in the Brazilian savanna (Cerrado), $\mathrm{Zn}$ availability is low and therefore its addition has been increasing crop yields (Alloway, 2004; Lopes, 1975; Ritchey et al., 1986).

The bioavailability and fate of $\mathrm{Zn}$ in soils is affected by both soil and source properties (Alloway, 2004). The formation of inner sphere complexes, precipitation at high $\mathrm{pH}$, and reaction with phosphates represent the main ways of sequestering $\mathrm{Zn}$ in the soil, potentially decreasing its availability for plant (Alloway, 2004; Oliveira et al., 1999; Sparks, 2005). Therefore, $\mathrm{Zn}$ fertilizers should be designed in order to avoid these processes that lead to the unavailability of $\mathrm{Zn}$ in the soil. Solubility, dispersion in soil and particle size are the most relevant characteristics of fertilizers affecting their agronomic effectiveness (Alloway, 2004; Gowariker, 2009; McBeath \& McLaughlin, 2014; Milani et al., 2012; Mortvedt, 1992).

Granular $\mathrm{Zn}$ fertilizers composed of water-insoluble $\mathrm{Zn}$ sources are interesting because of their reduced segregation and incompatibilities in fertilizer mixtures. In addition, insoluble $\mathrm{Zn}$ sources are easy to apply and can also prevent $\mathrm{Zn}$ losses, promoting a longer residual $\mathrm{Zn}$ availability for plants compared with conventional soluble sources (Mattiello et al., 2017; Santos et al., 2017). However, because of the longer disintegration time, granular fertilizers take longer to solubilize than powdered fertilizers (Gowariker, 2009), and may not provide enough $\mathrm{Zn}$ available for initial growth of the crops. Therefore, it is essential to make these properties compatible to improve fertilizer effectiveness.

Recent studies have demonstrated the agronomic potential of non-soluble $\mathrm{Zn}$ fertilizers, based on the co-granulation of $\mathrm{ZnO}$ with elemental sulfur $\left(\mathrm{S}^{\circ}\right)$, ES_Zn (Mattiello et al., 2017; Santos et al., 2017). ES_Zn fertilizer is also advantageous compared with soluble sources because it is cheaper and contains high concentration of $\mathrm{S}$, which is a macronutrient and generally poorly available in tropical soils.

The objective of this study was to evaluate the diffusion and plant availability of $\mathrm{Zn}$ from different sources in soils of contrasting textures.

\section{Materials and Methods}

\subsection{Soil and Zinc Fertilizers}

Because of the importance of the clay content in $\mathrm{Zn}$ dynamics, two soils with contrasting textures were used (sandy and clay soil). The soils were collected from 0-30 cm depth, sieved, placed into plastic bags, limed with a mixture of $\mathrm{CaCO}_{3}$ and $\mathrm{MgCO}_{3}$ to reach a $\mathrm{Ca}: \mathrm{Mg}$ ratio of $4: 1$ and $60 \%$ of base saturation, wetted to $80 \%$ of field capacity, and incubated for $30 \mathrm{~d}$. After that, soils were air-dried and sieved for physical and chemical analysis (Table 1-2 $\mathrm{mm}$ sieve), and to perform both the diffusion ( $1 \mathrm{~mm}$ sieve) and greenhouse trials (4 $\mathrm{mm}$ sieve).

For the present study, we used $\mathrm{Zn}$ sources of different solubilities and reactivities: zinc sulfate $\left[\left(\mathrm{ZnSO}_{4} \cdot 7 \mathrm{H}_{2} \mathrm{O}\right.\right.$; CAS: 7446-20-0; 22.74\% Zn)]; zinc oxide (ZnO; CAS: 1314-13-2; 80.34\% Zn); and a $\mathrm{ZnO}$ fertilizer pastilled with elemental sulfur $\left(\mathrm{S}^{\circ}\right)$ and bentonite (ES_Zn; $79.3 \% \mathrm{~S}^{\circ}, 4.2 \% \mathrm{Zn}, 10 \%$ Na-bentonite; granular form 2-3 $\mathrm{mm})$.

Table 1. Physical and chemical soil characteristics after liming

\begin{tabular}{lll}
\hline Soil characteristics & Sandy soil & Clay soil \\
\hline Sand $\left(\mathrm{g} \mathrm{kg}^{-1}\right)$ & 821 & 363 \\
Silt $\left(\mathrm{g} \mathrm{kg}^{-1}\right)$ & 25 & 106 \\
Clay $\left(\mathrm{g} \mathrm{kg}^{-1}\right)$ & 154 & 531 \\
$\mathrm{CEC} \mathrm{pH} 7.0\left(\mathrm{cmol}_{\mathrm{c}} \mathrm{dm}^{-3}\right)$ & 3.17 & 4.93 \\
$(\mathrm{H}+\mathrm{Al})\left(\mathrm{cmol}_{\mathrm{c}} \mathrm{dm}^{-3}\right)$ & 1.60 & 2.10 \\
$\mathrm{pH}($ water $)$ & 6.63 & 6.19 \\
$\mathrm{OM}\left(\right.$ dag kg $\left.^{-1}\right)$ & 1.3 & 1.5 \\
$\mathrm{Zn}\left(\mathrm{mg} \mathrm{dm}^{-3}\right)$ & 0.83 & 1.24 \\
\hline
\end{tabular}

Note. OM, organic matter content (Walkley \& Black, 1934). Available S $\left[\mathrm{Ca}\left(\mathrm{H}_{2} \mathrm{PO}_{4}\right)_{2} 500 \mathrm{mg} \mathrm{L}^{-1}\right.$ in acetic acid]. Available Zn (Mehlich-1). 


\subsection{Zinc Diffusion Trial}

A Petri dish trial was carried out to evaluate the diffusion of $\mathrm{Zn}$ in the soil. The experiment was designed as a factorial scheme $(3+1) \times 2 \times 3$, with three $\mathrm{Zn}$ sources (pastilled ES_Zn, $\mathrm{ZnO}$, and $\mathrm{ZnSO}_{4}$ ), one control treatment (without $\mathrm{Zn}$ application), two soils of contrasting textures (sandy and clay soil), and three incubation times $(1,30$ and $60 \mathrm{~d})$. The trial was carried out under a completely randomized design with four replications.

Approximately $20 \mathrm{~cm}^{3}$ of air-dried soil was placed in Petri dishes $(50 \mathrm{~mm}$ diameter $\times 10 \mathrm{~mm}$ height), ensuring a flat soil surface. A single pastille of ES_Zn fertilizer $(30 \pm 0.5 \mathrm{mg})$ was placed in the center of the Petri dish, at a depth of about $0.5 \mathrm{~cm}$. A $\mathrm{ZnSO}_{4}$ solution or $\mathrm{ZnO}$ suspension was applied by pipetting $15 \mu \mathrm{L}$ of solution or suspension into a small hole $(\sim 0.5-\mathrm{cm}$ deep) in the center of the Petri dish. All sources provided the same dose of $\mathrm{Zn}\left(66.3 \mathrm{mg} \mathrm{dm}^{-3}\right)$. After that, soils were carefully sprayed to reach $80 \%$ of field capacity, petri dishes were sealed with Parafilm to minimize water loss while maintaining aeration and incubated at $25{ }^{\circ} \mathrm{C}$.

Zinc diffusion was assessed according to the method proposed by Degryse et al. (2015), after 1, 30 and $60 \mathrm{~d}$ of incubation. In this method, filter papers (Whatman) were impregnated with $\mathrm{CaCO}_{3}$ and placed on the soil surface. After $2 \mathrm{~h}$ of reaction, the $\mathrm{CaCO}_{3}$-impregnated filter papers were collected, and the precipitated $\mathrm{Zn}$ in the papers was colored with dithizone, giving a pink color. After $30 \mathrm{~min}$, when the pink color was established, filters were air-dried and images scanned and processed using GIMP software (version 2.6.1). The diffusion radius (DR) was calculated through Equation 1.

$$
\mathrm{DR}=\sqrt{\mathrm{A} / \pi}
$$

where, $\mathrm{A}$ is the high-Zn dark pink colored area.

To measure the effect of source on Zn availability and soil acidity, only soil samples corresponding to 30 and 60 $\mathrm{d}$ treatments were used. Zinc availability was assessed using DTPA as an extractor (Lindsay \& Norvell, 1978) and soil $\mathrm{pH}$ was measured in a $1 / 2.5(\mathrm{w} / \mathrm{v})$ soil:water suspension. Soil samples were collected using a ring of $1.25 \mathrm{~cm}$ radius, with two separate soil sections (inner and outer), taking as reference the center of the Petri dish in which the fertilizers were applied. Samples were air-dried, sieved $(\leq 2 \mathrm{~mm})$, and homogenized to perform the analysis.

\subsection{Greenhouse Trial}

Agronomic performance of the $\mathrm{Zn}$ fertilizers was evaluated in a greenhouse pot experiment with a sequential cultivation of maize, soybean, and millet. This trial aimed to investigate the performance of $\mathrm{Zn}$ sources, including for their residual effects in a sequential cultivation, and the consistency of these results with $\mathrm{Zn}$ mobility demonstrated in the first trial (diffusion). Therefore, the trial was designed as a $2 \times(3 \times 3+1)$ factorial scheme: two soils (sandy and clay), three $\mathrm{Zn}$ sources $\left(\mathrm{ZnSO}_{4}, \mathrm{ZnO}\right.$, and $\left.\mathrm{ES} Z \mathrm{Zn}\right)$, three $\mathrm{Zn}$ doses (1.5, 3.0, and $6.0 \mathrm{mg} \mathrm{dm}^{-3} \mathrm{Zn}$ ), and a control treatment (no $\mathrm{Zn}$ application). The experiment was a randomized block design with four replications, being the experimental unit composed of a pot with $4 \mathrm{dm}^{3}$ of soil. Triple superphosphate (TSP) fertilizer was mixed into the sand and clay soils to supply 150 and $300 \mathrm{mg} \mathrm{dm}^{-3}$ of $\mathrm{P}$, respectively. Pastille ES_Zn, $\mathrm{ZnO}$ (as suspension), and $\mathrm{ZnSO}_{4}$ (as solution) were applied at five equidistant points, at $5 \mathrm{~cm}$ below the soil surface.

For the first cropping, six seeds of maize (Biomatrix BMB 20 commercial variety) were sown in each pot at a depth of $3 \mathrm{~cm}$ and thinned to the three most uniform ones in each pot. Solutions of N, K, and S were added 10, 20 , and $30 \mathrm{~d}$ after planting, giving total rates of $200 \mathrm{mg} \mathrm{dm}^{-3} \mathrm{~N}, 150 \mathrm{mg} \mathrm{dm} \mathrm{K}^{-3} \mathrm{~K}$, and $40 \mathrm{mg} \mathrm{dm}^{-3} \mathrm{~S}$. Micronutrients were also applied at the same time, totalizing $0.8 \mathrm{mg} \mathrm{dm}^{-3} \mathrm{~B}, 1.4 \mathrm{mg} \mathrm{dm}^{-3} \mathrm{Cu}, 1.6 \mathrm{mg} \mathrm{dm}^{-3} \mathrm{Fe}$, $3.7 \mathrm{mg} \mathrm{dm}^{-3} \mathrm{Mn}$, and $0.2 \mathrm{mg} \mathrm{dm}^{-3} \mathrm{Mo}$. After $30 \mathrm{~d}$ of cultivation maize shoots were harvested at the soil surface.

Twelve days after maize harvesting, six seeds of soybean (variety ND-7300) were sown into undisturbed soil pots at a depth of $2 \mathrm{~cm}$; after seedling emergence $(7 \mathrm{~d})$, the three most homogeneous seedlings were left in each pot. Seeds were inoculated with commercial Bradyrhizobium in order to fix and provide $\mathrm{N}$ to the plants. Macronutrients (K and S) were added 15 and $30 \mathrm{~d}$ after planting, giving a total of $200 \mathrm{mg} \mathrm{dm}^{-3} \mathrm{~K}$ and $60 \mathrm{mg} \mathrm{dm}^{-3}$ $\mathrm{S}$. After $60 \mathrm{~d}$, the shoots of the soybean were harvested by cutting the stems at the soil surface.

Ninety days after the soybean harvest, 15 seeds of millet (BRS 1501 cultivar) were sown in undisturbed soil pots at a depth of $2 \mathrm{~cm} ; 5 \mathrm{~d}$ after sowing, each pot was thinned to three plants. Nitrogen was applied to provide a total of $115 \mathrm{mg} \mathrm{dm}^{-3} \mathrm{~N}$. Plants were grown for $60 \mathrm{~d}$ and shoots were harvested every $20 \mathrm{~d}$ by cutting the stems at a height of $10 \mathrm{~cm}$ above the soil. 
For all crops, water availability was controlled daily to maintain the soil near $80 \%$ field capacity. The sequential cultivation resulted in 30, 102 and 252 days from $\mathrm{Zn}$ application to the harvesting of maize, soybean, and millet, respectively.

Plant materials were oven-dried at $70{ }^{\circ} \mathrm{C}$ for $72 \mathrm{~h}$ (until constant weight), weighed and milled for chemical analysis.

Plant samples were mineralized in an open-vessel digestion system using a nitric-perchloric solution $(3: 1 \mathrm{v} / \mathrm{v})$ (Miller \& Kalra, 1998). Zinc concentration in all extracts was quantified by atomic absorption spectroscopy (Agilent, Series AA Model 240 FS).

The $\mathrm{Zn}$ uptake $\left(\mathrm{Zn}_{\text {uptake }}\right)$ was calculated according to Equation 2:

$$
\mathrm{Zn}_{\text {uptake }}\left(\mathrm{mg} \text { pot }^{-1}\right)=\mathrm{Zn}_{\text {plant }} \times \mathrm{DM}
$$

where, $\mathrm{Zn}_{\text {plant }}$ is the concentration of $\mathrm{Zn}$ in plant tissue $\left(\mathrm{mg} \mathrm{g}^{-1}\right)$; and DM is the dry matter yield $\left(\mathrm{g} \mathrm{pot}^{-1}\right)$

The relative absorption efficiency (RAE) from each $Z n$ source was calculated according to Equation 3:

$$
\operatorname{RAE}(\%)=\left[\left(\mathrm{Zn}_{i}-\mathrm{Zn}_{0}\right) /\left(\mathrm{Zn}_{\text {ref }}-\mathrm{Zn}_{0}\right)\right] \times 100
$$

where, $\mathrm{Zn}_{i}$ is zinc uptake in treatments with added $\mathrm{Zn}$ fertilizer $\left(\mathrm{mg} \mathrm{pot}^{-1}\right) ; \mathrm{Zn}_{\text {ref }}$ is the zinc uptake obtained from $\mathrm{ZnSO}_{4}$ (reference fertilizer, RAE $=100 \%$ ); and $\mathrm{Zn}_{0}$ is the zinc uptake without addition of $\mathrm{Zn}$ fertilizer (control).

The recovery rate of $Z n\left(Z_{\text {Rec }}\right)$ for each treatment was calculated according to Equation 4 :

$$
\mathrm{Zn}_{\text {Rec }}(\%)=\left[\left(\mathrm{Zn}_{i}-\mathrm{Zn}_{0}\right) / \mathrm{Zn}_{\text {total }}\right] \times 100
$$

where, $\mathrm{Zn}_{i}$ is the $\mathrm{Zn}$ uptake from each treatment; $\mathrm{Zn}_{0}$ is the $\mathrm{Zn}$ uptake from the control treatment (without $\mathrm{Zn}$ ); and $\mathrm{Zn}_{\text {total }}$ is the total amount of $\mathrm{Zn}$ added as fertilizer.

\subsection{Data Statistical Processing}

Data were submitted to one-way analysis of variance. The effect of incubation time on $\mathrm{Zn}$ DR was evaluated by regression analysis, and the effect of fertilizers on soil properties, plant growth, and $\mathrm{Zn}$ absorption was compared by Tukey's test ( $\mathrm{p} \leq 0.05)$.

\section{Results}

\subsection{Zinc Diffusion}

The experimental results indicate that $\mathrm{Zn}$ diffusion evaluated by visualization test (Figure 1), and through its corresponding statistical approach (Figure 2), showed differences among fertilizers. After $1 \mathrm{~d}$ of incubation, $\mathrm{ZnSO}_{4}$ promoted significant $\mathrm{Zn}$ diffusion (Figures 1 and 2) compared with ZnO-based sources. After $1 \mathrm{~d}$, only a little spot of $\mathrm{Zn}$ diffusion was detected for $\mathrm{ZnO}$ and nothing for ES_Zn (Figure 1), for both soils.

Soil texture affects $\mathrm{Zn}$ diffusion. In sandy soil, $\mathrm{ZnSO}_{4}$ led to a higher $\mathrm{Zn} \mathrm{DR}$ at all incubation times, followed by that for $\mathrm{ZnO}$. From 1 to $30 \mathrm{~d}$, $\mathrm{Zn}$ DR increased for both $\mathrm{ZnSO}_{4}$ and $\mathrm{ZnO}$. However, from 30 to $60 \mathrm{~d}$ there was no increase in Zn DR for either source (Figures 2 and 3). From the ES_Zn, Zn diffusion in the sandy soil was low and occurred only after $60 \mathrm{~d}$. In the clay soil, differently from the sandy soil, the $\mathrm{Zn}$ DR increased linearly throughout the experimental time for all $\mathrm{Zn}$ sources. However, $\mathrm{ZnSO}_{4}$ also showed higher $\mathrm{Zn}$ DR followed by $\mathrm{ZnO}$. While $\mathrm{Zn} \mathrm{DR}$ increase from $\mathrm{ZnSO}_{4}$ and $\mathrm{ZnO}$ showed similar regression slopes ( 0.09 and 0.10 , respectively), ES_Zn showed a regression slope of 0.23 . Even though after $1 \mathrm{~d}$ ES_Zn had not released and diffused any $\mathrm{Zn}$ in the clay soil, within $30 \mathrm{~d}$ the Zn DR from ES_Zn was similar to the ZnO. Within $60 \mathrm{~d}$, Zn DR from ES_Zn was higher than from $\mathrm{ZnO}$ and similar to the $\mathrm{ZnSO}_{4}$. 


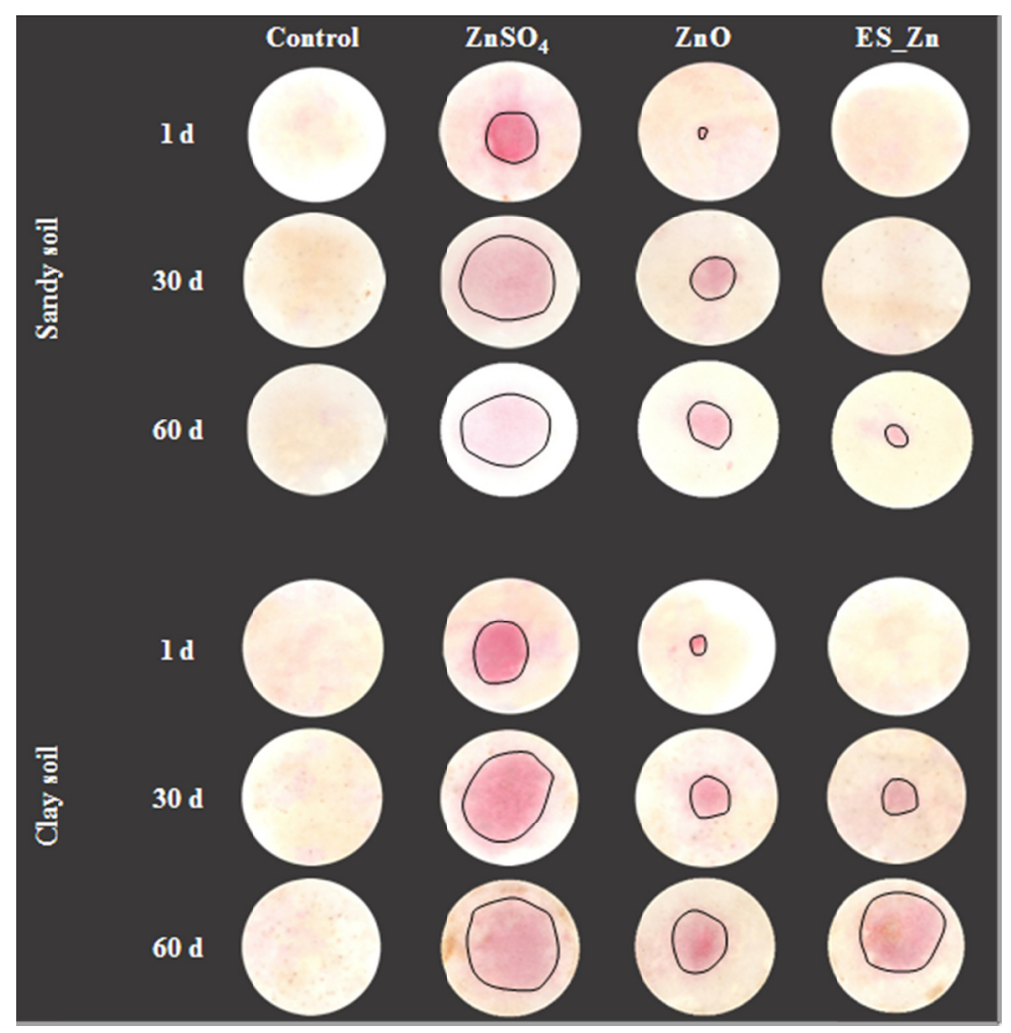

Figure 1. Visualization of $\mathrm{Zn}$ diffusion after 1, 30, and $60 \mathrm{~d}$ of incubation of different $\mathrm{Zn}$ fertilizers applied in the center of Petri dishes filled with soil of contrasting textures. ES_Zn is a commercial co-granulated Zn-enriched elemental sulfur fertilizer composed of $79.3 \% \mathrm{~S}^{0}, 4.2 \% \mathrm{Zn}$, and $10 \% \mathrm{Na}$-bentonite
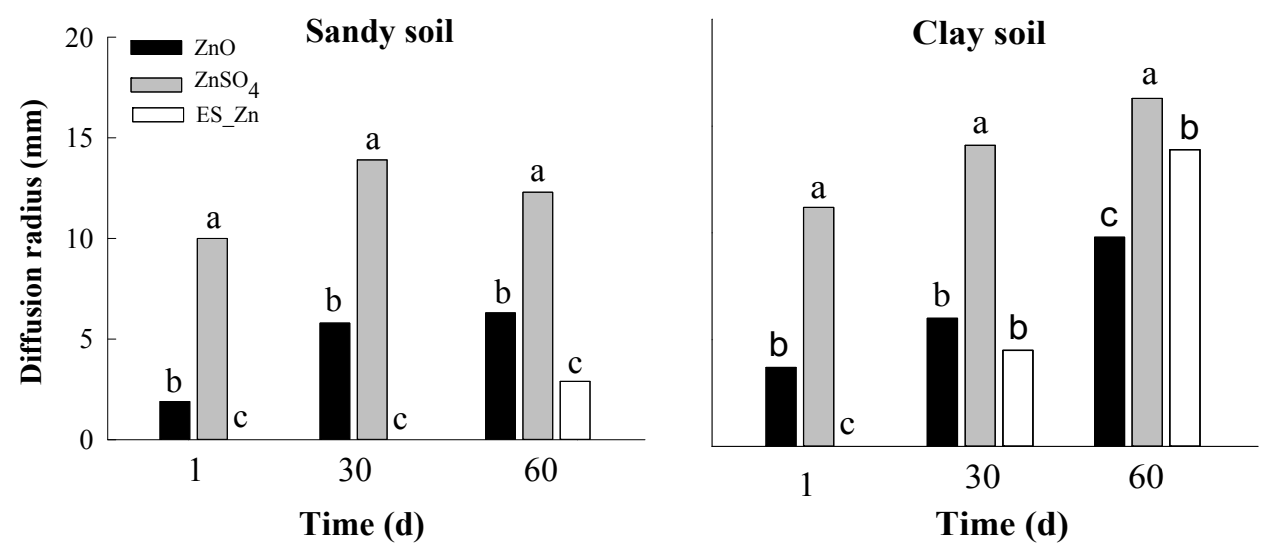

Figure 2. Radius of the $\mathrm{Zn}$ diffusion zone (Zn DR) after 1, 30, and $60 \mathrm{~d}$ of incubation of zinc fertilizers applied in the center of Petri dishes filled with soils of contrasting textures (see Materials and Methods). ES_Zn is a commercial co-granulated $\mathrm{Zn}$-enriched elemental sulfur fertilizer composed of $79.3 \% \mathrm{~S}^{0}, 4.2 \% \mathrm{Zn}$, and $10 \%$ Na-bentonite. Different letters within each incubation period indicate significant differences between treatments (Tukey test, $\mathrm{p} \leq 0.05$ ) 
Sandy soil

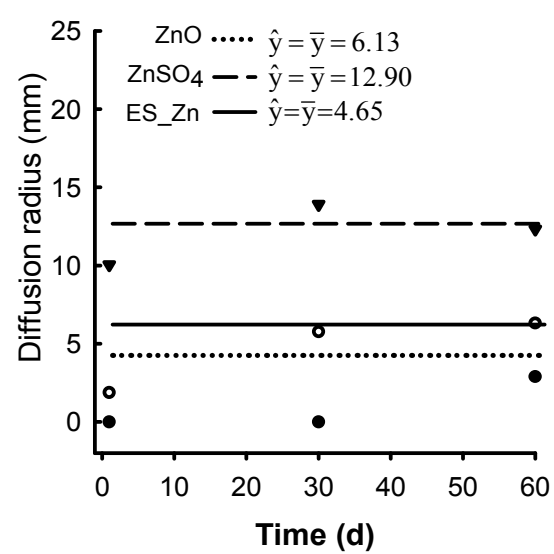

Clay soil

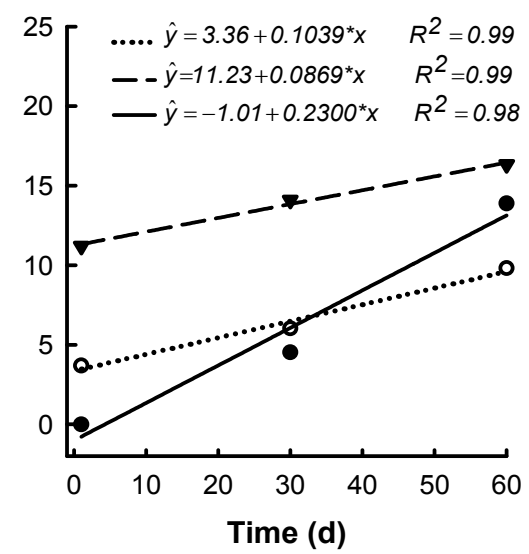

Figure 3. Radius of the $\mathrm{Zn}$ diffusion zone ( $\mathrm{Zn} \mathrm{DR}$ ) over incubation periods for $\mathrm{Zn}$ fertilizers applied in the center of Petri dishes filled with soils of contrasting textures. * indicates a significant effect by the t-test at $5 \%$. ES_Zn is a commercial co-granulated $\mathrm{Zn}$-enriched elemental sulfur fertilizer composed of $79.3 \% \mathrm{~S} 0,4.2 \% \mathrm{Zn}$, and $10 \%$

Na-bentonite

\subsection{Soil pH and Zinc Availability}

Reactions of $\mathrm{Zn}$ sources showed litter impact on soil $\mathrm{pH}$, but with statistical significance among sources when compared to the control treatment (Table 2). These effects were most significant in soil samples from the inner ring, because of their greater proximity to the application zone of the fertilizers. Overall, comparing with the control, $\mathrm{ZnSO}_{4}$ decreased soil $\mathrm{pH}$ in the inner and outer rings of almost all treatments, with exception for the sandy soil after $60 \mathrm{~d}$ of incubation (inner and outer ring) and the outer ring of the clay soil after $30 \mathrm{~d}$ of incubation. In a lesser extent, ES_Zn decreased pH in the inner ring of the clay soil after $30 \mathrm{~d}$ and in both inner and outer rings of the clay soil after $60 \mathrm{~d}$. On the other hand, $\mathrm{ZnO}$ increased $\mathrm{pH}$ in the inner ring of the sandy soil at 30 and $60 \mathrm{~d}$ of incubation (Table 2).

Zinc availability assessed by DTPA also demonstrated differences among sources (Table 2). For both soils and times, there was an increase in $\mathrm{Zn}$ availability in the inner ring for all sources, in contrast to the control treatment. In general, $\mathrm{ZnO}$ promoted higher $\mathrm{Zn}$ concentration (availability), followed by $\mathrm{ZnSO}_{4}$ and $\mathrm{ES}_{-} \mathrm{Zn}$. For the soil samples from the outer ring, only $\mathrm{ZnSO}_{4}$ increased $\mathrm{Zn}$ availability, demonstrating it to be the most effective source for transporting $\mathrm{Zn}$ in the soil. 
Table 2. Active soil acidity $(\mathrm{pH})$ and $\mathrm{Zn}$ availability as a function of different sources and soils with contrasting textures

\begin{tabular}{|c|c|c|c|c|c|c|c|c|}
\hline \multirow{4}{*}{ Source } & \multicolumn{8}{|c|}{ Incubation time (d) } \\
\hline & \multicolumn{4}{|c|}{$30 \mathrm{~d}$} & \multicolumn{4}{|c|}{$60 \mathrm{~d}$} \\
\hline & \multicolumn{2}{|c|}{ Sandy soil } & \multicolumn{2}{|c|}{ Clay soil } & \multicolumn{2}{|c|}{ Sandy soil } & \multicolumn{2}{|c|}{ Clay soil } \\
\hline & Inner & Outer & Inner & Outer & Inner & Outer & Inner & Outer \\
\hline \multicolumn{9}{|l|}{$p H$} \\
\hline Control & $6.4 \mathrm{~b}$ & $6.4 \mathrm{a}$ & $5.8 \mathrm{a}$ & $5.8 \mathrm{a}$ & $6.2 \mathrm{~b}$ & $6.3 \mathrm{a}$ & $5.7 \mathrm{a}$ & $5.6 \mathrm{a}$ \\
\hline $\mathrm{ZnSO}_{4}$ & $6.1 \mathrm{c}$ & $6.2 \mathrm{~b}$ & $5.5 \mathrm{~b}$ & $5.7 \mathrm{a}$ & $6.2 \mathrm{~b}$ & $6.2 \mathrm{a}$ & $5.4 \mathrm{bc}$ & $5.1 \mathrm{c}$ \\
\hline $\mathrm{ZnO}$ & $6.7 \mathrm{a}$ & $6.4 \mathrm{a}$ & $6.0 \mathrm{a}$ & $5.6 \mathrm{a}$ & $6.5 \mathrm{a}$ & $6.2 \mathrm{a}$ & $5.6 \mathrm{ab}$ & $5.4 \mathrm{ab}$ \\
\hline ES_Zn & $6.5 \mathrm{ab}$ & $6.4 \mathrm{a}$ & $5.4 \mathrm{~b}$ & $5.6 \mathrm{a}$ & $6.1 \mathrm{~b}$ & $6.2 \mathrm{a}$ & $5.1 \mathrm{c}$ & $5.2 \mathrm{bc}$ \\
\hline Mean & $6.4 \mathrm{~A}$ & $6.4 \mathrm{~A}$ & $5.7 C$ & $5.6 \mathrm{C}$ & $6.24 B$ & $6.2 \mathrm{~B}$ & $5.4 D$ & $5.3 \mathrm{D}$ \\
\hline \multicolumn{9}{|c|}{$\mathrm{Zn} \mathrm{DTPA}\left(m g d m^{-3}\right)$} \\
\hline Control & $0.5 \mathrm{~d}$ & $0.6 \mathrm{~b}$ & $0.7 \mathrm{~d}$ & $0.7 \mathrm{~b}$ & $0.4 \mathrm{~d}$ & $0.4 \mathrm{~b}$ & $0.6 \mathrm{~d}$ & $0.6 \mathrm{~b}$ \\
\hline $\mathrm{ZnSO}_{4}$ & $200.0 \mathrm{~b}$ & $38.4 \mathrm{a}$ & $137.2 \mathrm{~b}$ & $24.1 \mathrm{a}$ & $192.0 \mathrm{~b}$ & $43.0 \mathrm{a}$ & $109.3 \mathrm{~b}$ & $23.7 \mathrm{a}$ \\
\hline $\mathrm{ZnO}$ & $273.1 \mathrm{a}$ & $1.5 \mathrm{~b}$ & $188.6 \mathrm{a}$ & $1.5 \mathrm{~b}$ & $239.9 \mathrm{a}$ & $1.1 \mathrm{~b}$ & $164.3 \mathrm{a}$ & $3.5 \mathrm{~b}$ \\
\hline ES_Zn & $23.2 \mathrm{c}$ & $0.8 \mathrm{~b}$ & $33.9 \mathrm{c}$ & $1.3 \mathrm{~b}$ & $45.1 \mathrm{c}$ & $0.9 \mathrm{~b}$ & $54.5 \mathrm{c}$ & $3.8 \mathrm{~b}$ \\
\hline Mean & $124.2 \mathrm{~A}$ & $10.3 \mathrm{~A}$ & $90.1 B$ & $6.9 \mathrm{~B}$ & $119.3 \mathrm{~A}$ & $11.4 \mathrm{~A}$ & $82.2 C$ & $7.9 \mathbf{B}$ \\
\hline
\end{tabular}

Note. Means in the columns followed by different lowercase letters differ by the Tukey test at $5 \%$. Means in the rows followed by different capital letters in italics or bold letters differ from each other by the Tukey test at $5 \%$. ES_Zn is a commercial co-granulated $\mathrm{Zn}$-enriched elemental sulfur fertilizer composed of $79.3 \% \mathrm{~S}^{0}, 4.2 \% \mathrm{Zn}$, and $10 \%$ Na-bentonite. Inner refers to the inner sampling ring, and outer refers to the external sampling ring (see Materials and Methods).

\subsection{Crop Growth and Zinc Uptake}

There were no supporting evidences of differences among $\mathrm{Zn}$ sources on dry matter production (DMP) of any crop, within each soil (Table 3). However, for the maize and soybean crops, supplying $\mathrm{Zn}$ as $\mathrm{ZnSO}_{4}$ resulted in a higher DMP in clay soil than in sandy soil.

Significant increases in $\mathrm{Zn}$ absorption by crops, in terms of its concentration in shoots and accumulation ( $\mathrm{Zn}$ uptake), were observed only for the $\mathrm{ZnSO}_{4}$ (Table 3), which increased $\mathrm{Zn}$ uptake linearly for all crops with increasing dose (Figure 4). On the other hand, in the millet crop, both ES_Zn and ZnO promoted a similar linear increase in $\mathrm{Zn}$ uptake, most evident in clay soil (Figure 4). Moreover, when the sources were compared in terms of $\mathrm{Zn}$ recovery by crops, $\mathrm{ZnSO}_{4}$ always had a higher recovery rate for any soil and crop. However, in the clay soil, the millet crop recovered similar amounts of $\mathrm{Zn}$ from ES_Zn and $\mathrm{ZnSO}_{4}$ (Table 3). 
Table 3. Crop growth and zinc uptake in a successive maize-soybean-millet crop fertilized with sources of different solubility and reactivity in soils with contrasting textures

\begin{tabular}{|c|c|c|c|c|c|c|c|c|c|c|}
\hline \multirow{2}{*}{ Crop } & \multicolumn{5}{|c|}{ Sandy soil } & \multicolumn{5}{|c|}{ Clay soil } \\
\hline & Control & $\mathrm{ZnSO}_{4}$ & $\mathrm{ZnO}$ & ES_Zn & Mean & Control & $\mathrm{ZnSO}_{4}$ & $\mathrm{ZnO}$ & ES_Zn & Mean \\
\hline \multicolumn{11}{|c|}{ Shoot dry matter $\left(g\right.$ pot $\left.^{-1}\right)$} \\
\hline Maize & $31.7 \mathrm{a}$ & $34.1 \mathrm{a}$ & $31.0 \mathrm{a}$ & $31.7 \mathrm{a}$ & $32.1 \mathrm{~B}$ & $39.8 \mathrm{a}$ & $42.8 \mathrm{a}$ & $40.9 \mathrm{a}$ & $39.8 \mathrm{a}$ & $40.8 \mathrm{~A}$ \\
\hline Soybean & $13.6 \mathrm{a}$ & $14.4 \mathrm{a}$ & $15.0 \mathrm{a}$ & $14.6 \mathrm{a}$ & $14.5 \mathrm{~B}$ & $11.9 \mathrm{a}$ & $11.5 \mathrm{a}$ & $12.5 \mathrm{a}$ & $11.7 \mathrm{a}$ & $11.9 \mathrm{~A}$ \\
\hline Millet & $21.2 \mathrm{a}$ & $19.2 \mathrm{a}$ & $20.0 \mathrm{a}$ & $19.5 \mathrm{a}$ & $19.8 \mathrm{~A}$ & $21.9 \mathrm{a}$ & $20.8 \mathrm{a}$ & $19.2 \mathrm{a}$ & $20.5 \mathrm{a}$ & $20.6 \mathrm{~A}$ \\
\hline Total & $66.5 \mathrm{a}$ & $67.7 \mathrm{a}$ & $66.0 \mathrm{a}$ & $65.8 \mathrm{a}$ & $66.6 \mathrm{~B}$ & $73.6 \mathrm{a}$ & $75.1 \mathrm{a}$ & $72.6 \mathrm{a}$ & $72.0 \mathrm{a}$ & $73.3 \mathrm{~A}$ \\
\hline \multicolumn{11}{|c|}{ Zinc concentration $\left(\mathrm{mg} \mathrm{kg}^{-1}\right)$} \\
\hline Maize & $18.1 \mathrm{a}$ & $55.1 \mathrm{~b}$ & $22.4 \mathrm{a}$ & $23.2 \mathrm{a}$ & $29.7 \mathrm{~A}$ & $21.7 \mathrm{a}$ & $51.7 \mathrm{~b}$ & $24.0 \mathrm{a}$ & $23.1 \mathrm{a}$ & $30.1 \mathrm{~A}$ \\
\hline Soybean & $30.1 \mathrm{a}$ & $74.9 \mathrm{~b}$ & $39.7 \mathrm{a}$ & $39.0 \mathrm{a}$ & $45.9 \mathrm{~B}$ & $35.9 \mathrm{a}$ & $76.8 \mathrm{~b}$ & $61.6 \mathrm{a}$ & $53.7 \mathrm{a}$ & $57.0 \mathrm{~A}$ \\
\hline Millet & $55.9 \mathrm{a}$ & $168.0 \mathrm{~b}$ & $85.0 \mathrm{a}$ & $92.1 \mathrm{a}$ & $100.2 \mathrm{~A}$ & $72.2 \mathrm{a}$ & $117.2 \mathrm{a}$ & $97.9 \mathrm{a}$ & $111.5 \mathrm{a}$ & $99.7 \mathrm{~A}$ \\
\hline \multicolumn{11}{|c|}{ Zinc uptake (mg pot $\left.{ }^{-1}\right)$} \\
\hline Maize & $0.6 \mathrm{a}$ & $1.9 \mathrm{~b}$ & $0.7 \mathrm{a}$ & $0.7 \mathrm{a}$ & $1.0 \mathrm{~B}$ & $0.8 \mathrm{a}$ & $2.2 \mathrm{~b}$ & $1.0 \mathrm{a}$ & $1.0 \mathrm{a}$ & $1.2 \mathrm{~A}$ \\
\hline Soybean & $0.4 \mathrm{a}$ & $1.1 \mathrm{~b}$ & $0.6 \mathrm{a}$ & $0.6 \mathrm{a}$ & $0.7 \mathrm{~A}$ & $0.4 \mathrm{a}$ & $0.9 \mathrm{~b}$ & $0.8 \mathrm{a}$ & $0.6 \mathrm{a}$ & $0.7 \mathrm{~A}$ \\
\hline Millet & $1.1 \mathrm{a}$ & $3.2 \mathrm{~b}$ & $1.7 \mathrm{a}$ & $1.9 \mathrm{a}$ & $2.0 \mathrm{~A}$ & $1.3 \mathrm{a}$ & $2.5 \mathrm{~b}$ & $1.9 \mathrm{a}$ & $2.3 \mathrm{a}$ & $2.0 \mathrm{~A}$ \\
\hline Total & $2.1 \mathrm{a}$ & $6.2 \mathrm{~b}$ & $3.0 \mathrm{a}$ & $3.2 \mathrm{a}$ & $3.6 \mathrm{~A}$ & $2.5 \mathrm{a}$ & $5.6 \mathrm{~b}$ & $3.7 \mathrm{a}$ & $3.9 \mathrm{a}$ & $3.9 \mathrm{~A}$ \\
\hline \multicolumn{11}{|c|}{ Zinc recovery rate (\%) } \\
\hline Maize & - & $8.9 \mathrm{~b}$ & $2.0 \mathrm{a}$ & $1.9 \mathrm{a}$ & $4.3 \mathrm{~A}$ & - & $10.0 \mathrm{~b}$ & $1.4 \mathrm{a}$ & $3.5 \mathrm{a}$ & $5.0 \mathrm{~A}$ \\
\hline Soybean & - & $4.8 \mathrm{~b}$ & $2.2 \mathrm{a}$ & $2.4 \mathrm{a}$ & $3.1 \mathrm{~A}$ & - & $4.2 \mathrm{a}$ & $3.0 \mathrm{a}$ & $2.5 \mathrm{a}$ & $3.2 \mathrm{~A}$ \\
\hline Millet & - & $14.8 \mathrm{~b}$ & $5.0 \mathrm{a}$ & $4.9 \mathrm{a}$ & $8.2 \mathrm{~A}$ & - & $7.2 \mathrm{a}$ & $5.3 \mathrm{~b}$ & $8.2 \mathrm{a}$ & $6.9 \mathrm{~A}$ \\
\hline Total & - & $28.5 \mathrm{~b}$ & $9.2 \mathrm{a}$ & $9.2 \mathrm{a}$ & $15.6 \mathrm{~A}$ & - & $21.4 \mathrm{~b}$ & $9.7 \mathrm{a}$ & $14.2 \mathrm{a}$ & $15.1 \mathrm{~A}$ \\
\hline
\end{tabular}

Note. Means in the rows, within each soil, followed by different lowercase letters differ by the Tukey test at $5 \%$. Means in the rows followed by different capital letters differ by the F test at $1 \%$. ES_Zn is a commercial co-granulated $\mathrm{Zn}$-enriched elemental sulfur fertilizer composed of $79.3 \% \mathrm{~S}, 4.2 \% \mathrm{Zn}$, and $10 \%$ Na-bentonite. 

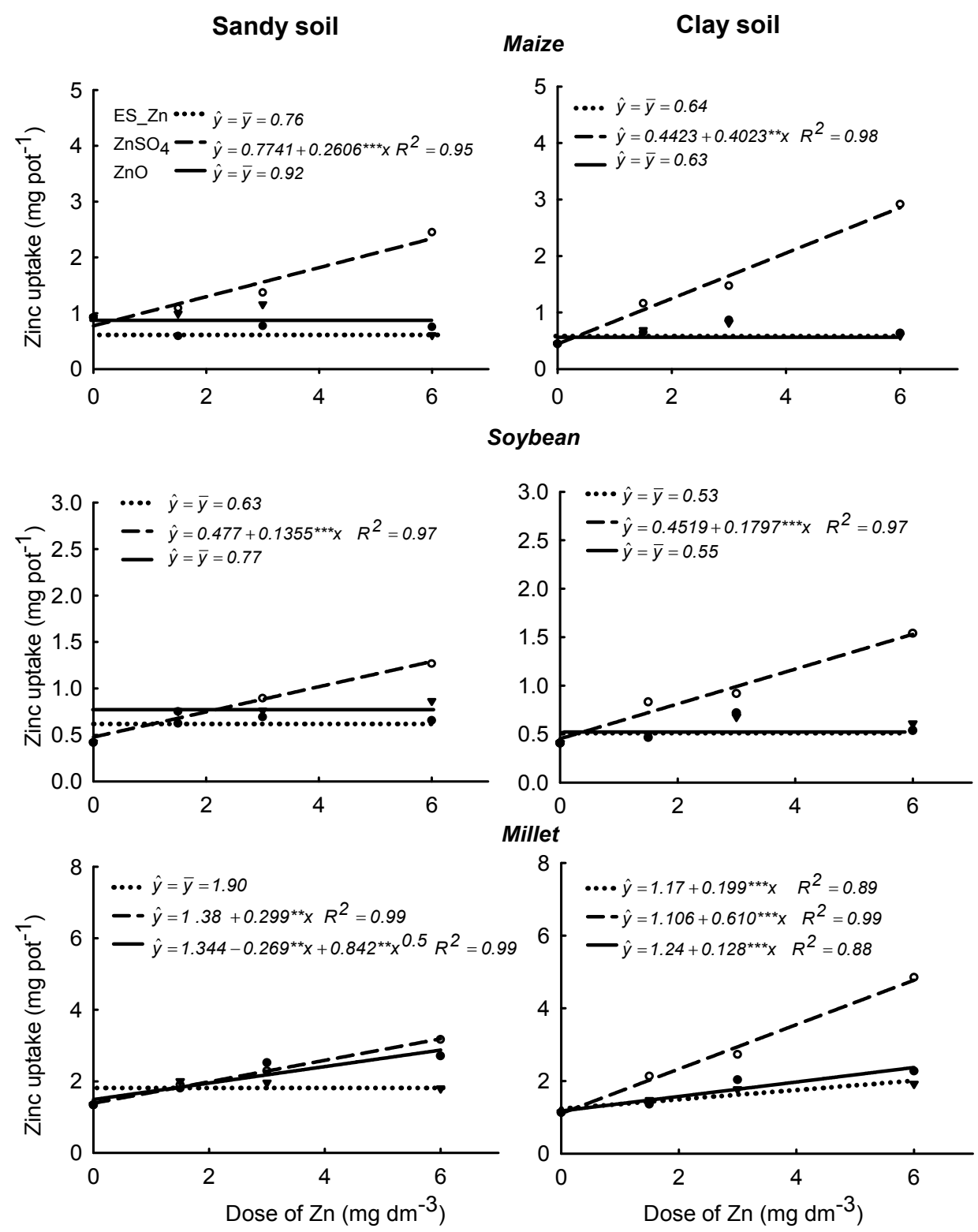

Figure 4. Shoot $\mathrm{Zn}$ uptake of successive maize-soybean-millet crops as a function of $\mathrm{Zn}$ dose for different fertilizers applied in soils of contrasting textures. ES_Zn is a commercial co-granulated $\mathrm{Zn}$-enriched elemental sulfur fertilizer composed of $79.3 \% \mathrm{~S}^{\circ}, 4.2 \% \mathrm{Zn}$, and $10 \%$ Na-bentonite. ${ }^{* *}$ and ${ }^{* * *}$ mean significant effects by the $t$-test at $1 \%$ and $0.1 \%$, respectively

The relative $\mathrm{Zn}$ absorption efficiency approach, RAE (Figure 5), reveals that ZnO-based fertilizers showed different trends over crop sequences compared with $\mathrm{ZnSO}_{4}$ fertilizer. In fact, while $\mathrm{ZnO}$ did not show any trend of RAE across the crops, ES_Zn showed a clear linear increase of RAE over the crop sequence, reaching $91 \%$ of RAE in the millet cultivated in the clay soil. In addition, soil texture affected the performance of ZnO-based fertilizers, being they in general most effective in clay soil (Figure 5). 

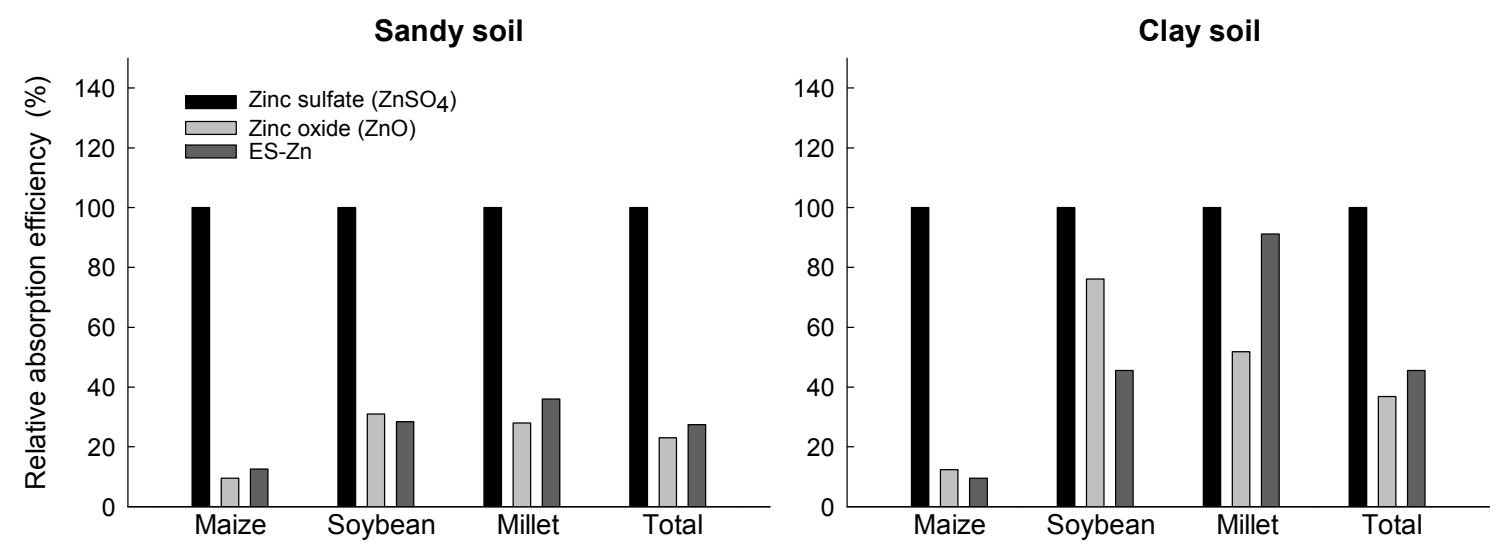

Figure 5. Relative absorption efficiency (RAE) of $\mathrm{Zn}$ in successive maize-soybean-millet crops as a function of different $\mathrm{Zn}$ fertilizers applied in soils of contrasting textures. ES Zn is a commercial co-granulated Zn-enriched elemental sulfur fertilizer composed of $79.3 \% \mathrm{~S}^{\circ}, 4.2 \% \mathrm{Zn}$, and $10 \%$ Na-bentonite

\section{Discussion}

The active acidity of soil (soil $\mathrm{pH}$ ) is a factor that can be affected by acid-base reactions in soil involving fertilizers. We suggest that $\mathrm{ZnSO}_{4}$ had an acidifying effect due to the acid residue on it and to the cationic exchange of $\mathrm{H}_{3} \mathrm{O}^{+}$by $\mathrm{Zn}^{2+}$ in the soil sorption complex, increasing the acidity of the soil solution. Indeed, a saturated solution of the $\mathrm{ZnSO}_{4}$ salt used in our study showed mild acidity ( $\mathrm{pH} \sim 5.2$ ).

Most $\mathrm{Zn}$ deficiency is reported in soils with $\mathrm{pH}$ higher than 6.0, due to its precipitation as oxyhydroxides or carbonate species (Alloway, 2004; Lindsay, 1991). In our work, the best performance of the ZnO-based fertilizers in clayey soil is probably due to its higher active acidity (soil $\mathrm{pH})$ and buffering capacity $(\mathrm{H}+\mathrm{Al}$ ), compared to the sandy soil (Table 1). Between $\mathrm{pH} 5.5$ and 7.0, $\mathrm{Zn}$ concentration in soil solution decreases about 30- to 40-fold when soil pH increases one unit (Moraghan \& Mascagni, 1991). In addition, its higher CEC helps removing $\mathrm{Zn}$ from the soil solution and increase solubilization.

Sulfur oxidation leading to a reduction in soil $\mathrm{pH}$ due to the use of ES_Zn has been reported by Mattiello et al. (2017), indicating that elementary sulfur $\left(\mathrm{S}^{\circ}\right)$ is oxidized in the soil (Santos et al., 2017). In fact, many native soil microorganisms oxidize sulfur, including chemolithotrophic and heterotrophic bacteria and fungi (Kumar et al., 2018; Luo et al., 2013). As demonstrated in Equation 5 (Santos et al., 2017), oxidation of $\mathrm{S}^{0}$ by soil microorganisms generates great amount of acidity. Therefore, the reduction in soil $\mathrm{pH}$ of the clay soil by ES_Zn fertilizer (Table 2) was due to proton production by microbial catalysis overcoming proton consumption to solubilize the $\mathrm{Zn} \_\mathrm{O}$ in the fertilizer. On the other hand, the increase in soil $\mathrm{pH}$ following $\mathrm{Zn} \_\mathrm{O}$ application can be attributed to the consumption of protons from the soil solution, as shown in Equation 6 (Santos et al., 2017). This finding also makes sense for our results because there was an increase in $\mathrm{Zn}$ availability using $\mathrm{ZnO}$, assessed by DTPA extractors.

$$
\begin{gathered}
\mathrm{S}^{\circ}+1.5 \mathrm{O}_{2}+\mathrm{H}_{2} \mathrm{O} \text { (Microorganism) } \rightarrow \mathrm{SO}_{4}^{2-}+2 \mathrm{H}^{+} \\
\mathrm{ZnO}+2 \mathrm{H}^{+} \rightarrow \mathrm{Zn}^{2+}+\mathrm{H}_{2} \mathrm{O}
\end{gathered}
$$

Zinc sulfate promotes greater $\mathrm{Zn}$ diffusion in the soil than $\mathrm{Zn} \_\mathrm{O}-$ based fertilizers (Mattiello et al., 2017). Despite the fact that $\mathrm{Zn} \_\mathrm{O}$ and $\mathrm{ZnSO}_{4}$ significantly increased $\mathrm{Zn}$ availability in the inner soil portion, only $\mathrm{ZnSO}_{4}$ increased it in the outer soil portion. We presumed that the greater diffusion of $\mathrm{Zn}^{2+}$ from $\mathrm{ZnSO}_{4}$ could be attributed to the higher $\mathrm{Zn}$ concentration promoted by such soluble source. Also, in some extent, $\mathrm{Zn}$ diffusion can benefit from the ionic interaction between $\mathrm{Zn}^{2+}$ and $\mathrm{SO}_{4}{ }^{2-}$ in the soil solution, as it has been demonstrated that $\mathrm{Zn}$ diffusion in soil is affected by the accompanying anions in soil solution (Oliveira et al., 1999), $\mathrm{Cl}^{-}$being more effective than $\mathrm{SO}_{4}{ }^{2-}$.

The results of $\mathrm{Zn}$ diffusion from the $\mathrm{ZnO}$, which happened from the first day of incubation, indicate that solubilization of this compound in soil is fast and can happen at high soil $\mathrm{pH}$ (e.g., at $\mathrm{pH} 6.6$ in sandy soil). A calculation for a single chemical system (Gustafsson, 2013) composed only of $\mathrm{Zn}^{2+}$ at $\mathrm{pH} 6.6$ demonstrates that the precipitation of $\mathrm{Zn}$ as $\mathrm{ZnO}$ occurs only when the $\mathrm{Zn}^{2+}$ concentration is higher than $1,512 \mathrm{mg} \mathrm{L}^{-1}$. Therefore, even accounting for physicochemical differences between this theoretical perspective and a real soil solution, 
including ionic force and the presence of other ions, data demonstrate that is possible to have a higher $\mathrm{Zn}$ concentration at this soil $\mathrm{pH}$.

The use of powder fertilizers are falling into disuse due to problems with application uniformity and segregation in fertilizer mixtures (Gowariker, 2009). On the other hand, granular fertilizers composed of insoluble nutrient sources, due to their small reaction surface area, promote retarded nutrient release into the soil solution, affecting plant nutrition. Indeed, the granular ES_Zn source promoted retarding on $\mathrm{Zn}$ releasing influencing both the diffusion of the element in soils as the effectiveness of the source as fertilizer.

Contrasting the lack of response of maize and soybean (two first crops) to the addition of $\mathrm{ZnO}$ with the diffusion trial results, there seems to be a contradiction, because of the high values achieved for available $\mathrm{Zn}$ using $\mathrm{ZnO}$, in the inner ring, at $30 \mathrm{~d}$ of incubation. However, as $\mathrm{ZnO}$ is a water-insoluble compound, its solubilization in soil is likely to depend on particle dispersion. Indeed, as $\mathrm{ZnO}$ was applied through a water suspension for the diffusion trial, we presume that in this condition there was no significant limitation for its solubilization, whereas when it was placed in small holes in the soil (greenhouse trial), there was greater inhibition of its dissolution because of the increase in soil $\mathrm{pH}$ around the $\mathrm{ZnO}$ particles due to proton consumption by dissolution (Milani et al., 2012). Therefore, join data of ES Zn and $\mathrm{ZnO}$ fertilizers lead us to report that both the physical form of $\mathrm{ZnO}$-based fertilizers and its dispersion in the soil are important factors to governing the dynamic of $\mathrm{Zn}$, affecting the dissolution pattern and agronomic effectiveness of the sources over time.

Only $\mathrm{ZnSO}_{4}$ was effective as a $\mathrm{Zn}$ source in terms of plant growth or $\mathrm{Zn}$ absorption for the first crops, while responses for $\mathrm{ZnO}$-based fertilizers were perceived only in the third crop (millet). This finding supports that to attend to the $\mathrm{Zn}$ demand for short crop cycles, fertilizers also need to contain water-soluble $\mathrm{Zn}$ forms. Mortvedt (1992) showed that at least $40 \%$ of the total $\mathrm{Zn}$ in granular fertilizers should be water-soluble to be fully effective for crops. In this sense, an ideal $\mathrm{Zn}$ fertilizer should contain both soluble and insoluble forms to meet both immediate and future plant demands by promoting balanced nutrient release over time.

Despite the similarity in plant response to ZnO and ES_Zn fertilizers, the latter is advantageous because it is in granular form and contains high concentration of $\mathrm{S}^{0}$, which is a highly required plant nutrient and generally deficient in tropical soils. Despite the best performance being displayed by $\mathrm{ZnSO}_{4}$, this salt presents physical and chemical incompatibilities for compound solid fertilizer mixtures, associated with its high hygroscopicity.

\section{Conclusion}

In conclusion, $\mathrm{Zn}$ diffusion in soil is higher for $\mathrm{ZnSO}_{4}$ compared with $\mathrm{ZnO}$-based fertilizers, supposedly due to the ionic interaction between $\mathrm{SO}_{4}{ }^{2-}$ and $\mathrm{Zn}^{2+}$. Our results also support that $\mathrm{ZnO}$ can be dissolved in soil at high $\mathrm{pH}$ (6.6) and suggest that its dispersion in soil affects the solubilization rate. Moreover, solubilization of the co-granulated $\mathrm{Zn}$-enriched elemental sulfur fertilizer (ES_Zn) is delayed in soil, affecting its efficiency as fertilizer. Thereby, $\mathrm{ZnSO}_{4}$ is the most effective fertilizer regardless of crop sequence. Therefore, these findings suggest that an ideal $\mathrm{Zn}$ fertilizer should contain both soluble and insoluble $\mathrm{Zn}$ sources, aiming to attend plants' demands throughout their whole cycle.

\section{References}

Alloway, B. J. (2004). Zinc in soils and crop nutrition. International Zinc Association, Brussels.

Cakmak, I. (2008). Enrichment of cereal grains with zinc: Agronomic or genetic biofortification? Plant and Soil, 302, 1-17. https://doi.org/10.1007/s11104-007-9466-3

Degryse, F., Baird, R., \& McLaughlin, M. J. (2015). Diffusion and solubility control of fertilizer-applied zinc: Chemical assessment and visualization. Plant and Soil, 386, 195-204. https://doi.org/10.1007/s11104014-2266-7

Gowariker, V. (2009). The fertilizer enciclopedia. Wiley.

Gustafsson, J. P. (2013). Visual MINTEQ 3.1 User Guide. KTH, Department of Land and Water Recources, Stockholm, Sweden.

Kumar, U., Panneerselvam, P., Gupta, V. V., Manjunath, M., Priyadarshinee, P., Sahoo, A., ... Annapurna, K. (2018). Diversity of Sulfur-Oxidizing and Sulfur-Reducing Microbes in Diverse Ecosystems Advances in Soil Microbiology: Recent Trends and Future Prospects (pp. 65-89). Springer.

Lindsay, W. (1991). Inorganic equilibria affecting micronutrients in soils. In J. J. Mortvedt., F. R. Cox., L. M. Shuman, \& R. M. Welch (Eds.), Micronutrients in agriculture (pp. 89-112). Madison, Wisconsin, USA. 
Lindsay, W. L., \& Norvell, W. A. (1978). Development of a DTPA soil test for zinc, iron, manganese, and copper. Soil Science Society of America Journal, 42, 421-428. https://doi.org/10.2136/sssaj1978. 03615995004200030009x

Lopes, A. S. (1975). A survey of the fertility status of soils under “Cerrado” vegetation in Brazil.

Luo, J., Tian, G., \& Lin, W. (2013). Enrichment, isolation and identification of sulfur-oxidizing bacteria from sulfide removing bioreactor. Journal of Environmental Sciences, 25(7), 1393-1399. https://doi.org/10.1016/ S1001-0742(12)60179-X

Mattiello, E. M., da Silva, R. C., Degryse, F., Baird, R., Gupta, V. V., \& McLaughlin, M. J. (2017). Sulfur and Zinc Availability from Co-granulated Zn-Enriched Elemental Sulfur Fertilizers. Journal of Agricultural and Food Chemistry, 65, 1108-1115. https://doi.org/10.1021/acs.jafc.6b04586

McBeath, T., \& McLaughlin, M. (2014). Efficacy of zinc oxides as fertilisers. Plant and Soil, 374, $843-855$. https://doi.org/10.1007/s11104-013-1919-2

Milani, N., McLaughlin, M. J., Stacey, S. P., Kirby, J. K., Hettiarachchi, G. M., Beak, D. G., \& Cornelis, G. (2012). Dissolution kinetics of macronutrient fertilizers coated with manufactured zinc oxide nanoparticles. Journal of Agricultural and Food Chemistry, 60, 3991-3998. https://doi.org/10.1021/jf205191y

Miller, R. O. (1998). Nitric-perchloric acid wet digestion in an open vessel. In Y. P. Kalra (Ed.), Handbook of Reference Methods for Plant Analysis. CRC Press, Boca Raton, USA.

Moraghan, J., \& Mascagni, H. (1991). Environmental and soil factors affecting micronutrient deficiencies and toxicities. In J. J. Mortvedt., F. R. Cox., L.M. Shuman, \& R. M. Welch (Eds.), Micronutrients in agriculture (pp. 371-425). Madison, Wisconsin, USA. https://doi.org/10.2136/sssabookser4.2ed.c11

Mortvedt, J. (1992). Crop response to level of water-soluble zinc in granular zinc fertilizers. Fertilizer Research, 33, 249-255. https://doi.org/10.1007/bf01050880

Oliveira, M. F. G., Novais, R. F., Neves, J. C. L., Alves, V. M. V., \& Vasconcellos, C. A. (1999). Fluxo difusivo de zinco em amostras de solo influenciado por textura, íon acompanhante e pH do solo. Revista Brasileira de Ciência do Solo, 23, 609-615. https://doi.org/10.1590/s0100-06831999000300014

Ritchey, K. D., Cox, F. R., Galrão, E. Z., \& Yost, R. S. (1986). Disponibilidade de zinco para as culturas do milho, sorgo e soja em Latossolo Vermelho-Escuro argiloso. Pesquisa Agropecuária Brasileira, 21, 215-225.

Santos, W. O., Mattiello, E. M., Vergutz, L., \& Matias, P. C. (2017). Production and evaluation of a co-granulated elemental sulfurmicronutrient fertilizer. International Journal of Agronomy and Agricultural Research, 10, 14-23.

Sparks, D. L. (2005). Toxic metals in the environment: The role of surfaces. Elements, 1, $193-197$. https://doi.org/10.2113/gselements.1.4.193

Walkley, A., \& Black, I. A. (1934). An examination of the Degtjareff method for determining soil organic matter, and a proposed modification of the chromic acid titration method. Soil Science, 37, 29-38. https://doi.org/ 10.1097/00010694-193401000-00003

\section{Copyrights}

Copyright for this article is retained by the author(s), with first publication rights granted to the journal.

This is an open-access article distributed under the terms and conditions of the Creative Commons Attribution license (http://creativecommons.org/licenses/by/4.0/). 